ARTigo

\title{
A ATUAÇÃO DA IMPRENSA CATÓLICA DURANTE O GOVERNO MILITAR NO BRASIL
}

\author{
THE PERFORMANCE OF THE CATHOLIC PRESS DURING THE BRAZILIAN \\ MILITARY GOVERNMENT
}

\author{
Newton Leonardo Silva* \\ Vera Chaia**
}

\begin{abstract}
RESUMO
Para compreender como se deu a relação entre a Igreja Católica e o governo militar brasileiro nos Anos de Chumbo e como se construiu esse jogo de interesses entre as duas instituiçöes com mais poder politico no cenário nacional, é realizado o estudo das matérias publicadas no jornal da Cúria Metropolitana de São Paulo, O São Paulo. O período estudado vai de novembro de 1970, quando D. Paulo Evaristo Arns é nomeado para ser o quinto Arcebispo de São Paulo; e março de 1974, quando chega ao fim o governo mais repressor do periodo ditatorial, o comandado pelo general Emílio Garrastazú Médici. Com o estudo, verificou-se que o jornal, apesar da censura, fez uma cobertura extremamente opinativa. Tal fato traduz o espirito do arcebispo à frente da cidade de São Paulo, D. Paulo Evaristo Arns, que optou pelo enfrentamento aos militares de forma respeitosa e diplomática, e em território nacional.
\end{abstract}

PALAVRAS-CHAVE: Ditadura Militar. Igreja Católica. Imprensa.

\begin{abstract}
To understand how a relationship between the Catholic Church and Brazilian Military Government occurred in the "Lead Years" and how this game of interests was constructed between the two institutions with more political power on the national scene, the study of the articles published in the newspaper of the Metropolitan Curia of São Paulo is carried out, "O São Paulo". The period studied is from November 1970, when D. Paulo Evaristo Arns is appointed to be the fifth Archbishop of São Paulo; and March 1974, when the most repressive government of the dictatorial period came to an end, the one commanded by general Emilio Garrastazú Médici. With the study, it was found that the newspaper, despite censorship, it made an extremely opinionated coverage. Such fact reflects the spirit of the archbishop in front of the city of São Paulo, D. Paulo Evaristo Arns, who opted to confront the military in a respectful and diplomatic way, and in national territory.
\end{abstract}

KEYWORDS: Catholic Church. Military Dictatorship. Press.

\footnotetext{
* Mestrado em Ciências Sociais pela Pontifícia Universidade Católica de São Paulo (PUC-SP). Email: n.leonardosilva84@gmail.com

** Professora da Pontifícia Universidade Católica de São Paulo (PUC-SP). Doutorado em Ciência Política pela Universidade de São Paulo (USP). Pós-Doutorado pela Universidad Rey Juan Carlos (URJC), Espanha. Email: vmchaia@pucsp.br
} 


\section{INTRODUÇÃO}

Diante do atual cenário político brasileiro, no qual, cada vez com mais frequência e visibilidade, há uma escalada de citações, referências e até elogios a regimes totalitários por parte de integrantes governamentais ${ }^{1}$, este artigo faz uma breve exposição de como foi a relação entre Igreja Católica e o governo militar no Brasil entre os anos de 1970 e 1974, tendo por base o veículo da Cúria Metropolitana de São Paulo, o jornal O São Paulo. Como diz Mainwaring (2004, p. 11, grifo nosso), "A questão não é se a Igreja está ou não envolvida na política, mas como ela está envolvida".

Dois momentos significativos foram escolhidos para serem os marcos inicial e final de estudo dentro deste período: o marco inicial é o mês de novembro de 1970, quando D. Paulo Evaristo Arns, então responsável pela Pastoral Carcerária, é nomeado pelo papa Paulo VI para ser o quinto Arcebispo de São Paulo, sucedendo o conservador D. Agnelo Rossi; já o mês de março de 1974, quando chega ao fim o governo mais repressor do período ditatorial, o comandado pelo general Emílio Garrastazu Médici, é o momento em que se encerra o estudo do periódico. Neste período repressivo, as liberdades individuais foram cerceadas e as atividades da imprensa brasileira acompanhadas de perto pelos censores. Como consequência a este aumento na repressão, muitos veículos tradicionais deixaram de existir e outros, mais radicais e revolucionários, passaram a integrar, mesmo que clandestinamente e sem uma periodicidade definida, o cenário nacional.

Neste panorama de perseguições à mídia tradicional, as publicações católicas emergem como um importante diferencial, uma vez que, usufruindo de seu prestígio perante a sociedade brasileira e aos campos sociais estabelecidos no Brasil, incluindo o campo político e militar, passa a divulgar em suas páginas os atos e/ou acontecimentos que o regime proibia em outras publicações, em uma atitude de clara resistência aos desmandos do governo militar. Daí a importância de se analisar as matérias veiculadas no semanário da Cúria Metropolitana de São Paulo.

A primeira edição d’ O São Paulo foi publicada em 25 de janeiro de 1956, com o lema "Veritatis et Sobrietatis Verba Loquor" ou "Digo palavras de Verdade e Prudência", passagem do livro do Atos dos Apóstolos, capítulo 26, versículo 25. No texto de apresentação, o cardeal D. Carlos Carmelo de Vasconcelos Motta, então arcebispo de São Paulo, sintetizava o motivo para o nome do jornal: "É um título que é mais do céu do que da Terra".

Em 1964, ano do golpe civil-militar, o jornal continha oito páginas, era dirigido por D. Marchetti Zioni e já dava indícios de ter se transformado em um veículo que era mais da Terra do que do Céu, trazendo matérias de cunho social e político. Em 1969, o semanário já sofria com a autocensura imposta

\footnotetext{
${ }^{1}$ No período de um ano e meio do governo Jair Bolsonaro já aconteceram três trocas de Ministros da Educação, sendo que o primeiro deles chegou a sinalizar que poderia rever e reescrever, nos livros de História, o que se passou entre os anos de 1964 e 1985, ressignificando e relativizando o que aqui chamamos de Ditadura Militar. Além disso, o próprio Presidente já chegou a homenagear, quando era Deputado Federal, o coronel Carlos Humberto Brilhante Ustra, primeiro militar a ser reconhecido como torturador pela Justiça.
} 
por D. Agnelo Rossi, arcebispo de São Paulo e presidente da Conferência Nacional dos Bispos do Brasil (CNBB), que proibiu o editor do jornal, o padre Amaury Castanho, de publicar um editorial contra a tortura (SERBIN, 2001, p. 104). Ainda no mesmo ano, a publicação passa a ser dirigida por D. Paulo Evaristo Arns, que fica no posto até o mês de outubro, quando é criado o Centro de Informações Ecclesia (CIEC), com pretensões de ser uma espécie de agência de notícias da Igreja. Então, a direção do periódico passa para o Cônego Amaury Castanho que se mantém no cargo durante o período estudado.

Ao longo do artigo, se verá termos divisionistas como "progressista", "conservador", "moderado", entre outros. Porém, é de fundamental importância sempre estar subentendido que esta divisão era muito mais homogênea (com itens extremamente sutis e variados servindo de parâmetro para a divisão), além de complexa e numerosa, do que se imagina. A linha aqui adotada é a mesma defendida pelo autor Kenneth Serbin (2001, p. 10): "por maior que seja a tentação, a história não deve ser vista de forma maniqueísta, mas sim como conflitos entre indivíduos cujas personalidades e atitudes têm sido esculpidas por numerosos fatores históricos"; ou por Paulo Cesar Gomes (2014, p. 17), de que não há como entender a relação entre as duas instituições como uma simples contraposição entre o Estado que reprime e a Igreja que resiste. Houve várias ocasiões de diálogo, mesmo nos períodos mais tensos, e a ruptura total entre eles nunca existiu.

\section{IGREJA CATÓLICA E ESTADO}

Por meio da pesquisa realizada para este artigo, verificou-se que a ditadura militar brasileira, imposta na virada de 31 de março para o $1^{\circ}$ de abril de 1964, marca o início de um novo período na relação entre Igreja Católica e Estado do Brasil. Presente desde 1549 em solo brasileiro, a Igreja Católica, em raras ocasiões, como no fenômeno da Questão Religiosa que contribuiu para o fim da monarquia no país, questionou o alinhamento político com o Estado. A ditadura militar foi, sem dúvidas, o período em que a instituição religiosa não ficou apenas no questionamento, mas partiu para a ação, por vezes radical, na oposição às ações do governo. A mudança de postura da Igreja no Brasil, entretanto, foi realizada gradualmente, ao longo dos anos da ditadura, como uma onda que se iniciou lá em 1962, em Roma, com o Concílio Vaticano II, veio crescendo e teve sua arrebentação após a decretação do Ato Institucional mais repressor da história do regime, o AI-5.2

Considerado a mais ampla reforma da história da Igreja (SERBIN, 2001), o Concílio Vaticano II, durou quatro anos (entre 1962 e 1965), reuniu mais de dois mil bispos e centenas de teólogos de

\footnotetext{
2 Baixado em 13 de dezembro de 1968, o Ato Institucional No 5 é conhecido como o mais repressivo da ditadura militar no Brasil. Considerado um golpe dentro do golpe, pois os poderes do presidente ficavam acima dos estabelecidos pela Constituição de 1967, autorizava o mandatário, sem apreciação judicial, a: decretar o recesso do Congresso Nacional; intervir nos estados e municípios; cassar mandatos parlamentares; suspender, por dez anos, os direitos políticos; decretar o confisco de bens considerados ilícitos; e suspender a garantia do habeas-corpus. O AI-5 vigorou até dezembro de 1978.
} 
várias nacionalidades e instituiu várias novidades. A primeira delas foi justamente a indicação do sucessor do Papa que convocou o Concílio, João XXIII, morto em junho de 1963. Foi então que monsenhor Giovanni Battista Montini, muito próximo dos bispos brasileiros, tornou-se o papa Paulo VI, cabeça da Igreja durante o período estudado. Além dessa mudança, outra muitas, como a missa nas línguas nacionais e até a mudança nas vestimentas dos prelados, foram colocadas em prática após o Concílio.

Outro momento que marca essa transição da Igreja foi a II Assembleia Geral do Conselho Episcopal Latino-americano (CELAM), realizada em Medellín, no ano de 1968, na qual os bispos elaboraram uma declaração clamando por justiça social e condenando o subdesenvolvimento e a violência na América Latina.

Medellín também marcou o início de um novo movimento dentro da Igreja no mundo, a chamada Teologia da Libertação. Com seu método ver-julgar-agir, a Teologia da Libertação, nas palavras de Leonardo Boff (BOFF, L; BOFF, C, 2007), era toda forma de pensar a fé ante a opressão, se colocando em oposição nítida ao capitalismo e ao imperialismo e chegando a defender conceitos marxistas como a luta de classes, algo impensável até anos anteriores.

Essas transformações foram realizadas como uma resposta às cobranças e à necessidade da Igreja Católica de posicionar-se e de se autodefinir em um mundo polarizado entre Capitalismo e Socialismo e que estava passando por rápidas e constantes mudanças, interpretadas por historiadores como verdadeiras "revoluções" nos mais diversos campos: sexual, cultural, político, comportamental.

O problema é que, logo que a ditadura é instaurada, a Igreja Católica no Brasil encontrava-se dividida entre a ala progressista, que teve participação importante no Concilio Vaticano II e terá na II Assembleia Geral do CELAM, em Medellín, com bispos como D. Helder Câmara, D. Avelar Brandão Vilela e D. Eugênio de Araújo Sales, desempenhando papel de liderança nessas reuniões; e a ala conservadora que, em território nacional, subordinava os bispos progressistas, tendo na figura de D. Agnelo Rossi - então arcebispo de São Paulo e presidente da CNBB - o expoente mais influente dessa corrente de pensamento. Por este motivo, é que se verifica que, até o início da década de 1970, alas da Igreja ainda tentavam, em vão, negociar uma saída amigável e burocrática para os "exageros" cometidos por membros do regime contra militantes em geral e contra católicos em particular.

No que se refere às matérias do jornal O São Paulo e à cobertura realizada no período inicial do regime ditatorial, constata-se que, devido à pressão dos militares e estando subordinado à ala conservadora do episcopado, em especial do arcebispo de São Paulo, o periódico fará uma cobertura visando descolar a imagem da CNBB das ações dos perseguidos, adotando uma postura neutra em relação a eles, sempre afirmando esperar as decisões da justiça para se pronunciar com mais exatidão a respeito dos casos.

D. Agnelo Rossi, até por causa de sua dupla investidura de Arcebispo e presidente da CNBB, é presença constante nas páginas do jornal no período, assinando artigos que tinham como intuito 
principal disfarçar a omissão da CNBB em relação aos atos repressivos do governo, inclusive aqueles perpetrados contra membros da Igreja, e tentar demonstrar que alguma ação estava sendo praticada.

Duas situações são exemplares para demonstrar a ação omissa de D. Agnelo no período inicial da Ditadura Militar. Presos no sábado, $1^{\circ}$ de novembro de 1969 e utilizados como iscas para a tentativa de captura do líder da Ação Libertadora Nacional (ALN), Carlos Marighella ${ }^{3}$ - morto na emboscada de 4 de novembro - os dominicanos só tiveram a notícia de sua prisão divulgada pelo O São Paulo na segunda edição, dois sábados depois da prisão, em 15 de novembro.

$\mathrm{Na}$ nota, reproduzida na íntegra pelo periódico, D. Agnelo afirma não requerer regalias aos prelados só porque o são, mas pede que a garantia aos direitos humanos seja observada, deixando transparecer a preocupação com as torturas (O São Paulo, 15 de novembro de 1969, p. 1).

No dia 29 de novembro, outra nota, redigida em terceira pessoa, afirma que o arcebispo visitara os dominicanos presos e, surpreendentemente, afirma: "Nenhum deles apresentava sinais de violências e nem mesmo aludiram a elas. Encontravam-se todos de saudável aspecto físico e psíquico" (O São Paulo, 29 de novembro de 1969, p. 1). Frei Tito, que se suicidaria em 10 de agosto de 1974, em Paris, vítima de problemas psíquicos causados justamente pelas torturas sofridas, poderia esclarecer melhor D. Agnelo.

O segundo caso demonstrativo da omissão de D. Agnelo é a repercussão da denúncia de que a tortura no Brasil era institucionalizada, que D. Helder fizera em Paris, em maio de 1970, e uma consequente campanha difamatória ao prelado. Nem para defender seu companheiro de arcebispado D. Agnelo demonstra-se animado a se opor ao regime. Pelo contrário, desautoriza as declarações de D. Helder e responsabiliza unicamente o arcebispo pelas suas declarações.

D. Agnelo só tomaria uma postura mais enérgica na defesa do arcebispo de Recife e Olinda quando o governador paulista chama D. Helder de "Fidel Castro de batina" e o acusa de auxiliar o Partido Comunista. Mesmo após essa grave acusação, o presidente da CNBB, juntamente com outros bispos brasileiros, se vễ na "constrangedora” situação de exigir, apenas, explicações à Abreu Sodré.

A maior prova de que D. Agnelo Rossi e a ala conservadora que ditava os rumos da Igreja no Brasil estavam aquém dos ideais defendidos pelo Vaticano desde o Concílio de 1962 - ou seja, uma ação mais voltada para a justiça social e os direitos humanos - é que, em outubro de 1970, o papa Paulo VI nomeia D. Agnelo Rossi para um cargo burocrático em Roma, colocando em seu lugar, na arquidiocese de São Paulo, o responsável pela Pastoral Carcerária, D. Paulo Evaristo Arns. No ano seguinte, em 1971,

\footnotetext{
3 Carlos Marighella foi escritor, guerrilheiro e político, tendo vivenciado (e se oposto) a dois regimes autoritários: o Estado Novo (1937-1945) e a Ditadura Militar (1964-1985). Ainda em 1936, se filiou ao Partido Comunista Brasileiro (PCB), foi deputado federal pelo partido, em 1946, mas perdeu o mandato no mesmo ano, assim como todos os filiados a partidos comunistas. Por divergências políticas, foi expulso do PCB em 1967. No ano seguinte, em 1968, fundou a Ação Libertadora Nacional (ALN), com dissidentes do partido. Com o recrudescimento do regime, após 1968, chegou a ser considerado o inimigo número um da ditadura e recebeu o codinome de professor Menezes. Na noite de 4 de novembro de 1969, Marighella foi morto em uma emboscada, montada por agentes do Departamento de Ordem Política e Social (DOPS), na Alameda Casa Branca, quando ia encontrar-se com dois dominicanos que ajudavam em algumas ações da ALN.
} 
outro membro que combatia o regime militar substitui D. Agnelo, desta vez na presidência da CNBB. Assumiria o cargo D. Alóisio Lorscheider que, em outubro de 1970, fora preso pelos militares e mantido incomunicável, no cárcere, por horas.

Com a ascensão de D. Paulo no arcebispado paulista e de D. Aloísio na presidência da CNBB, O São Paulo agirá de forma mais atuante na oposição ao regime. Prova dessa mudança de posição do periódico e da importância que este tinha no cenário nacional é que, em março de 1971, começam os telefonemas e bilhetes ameaçadores à redação de O São Paulo e, em novembro de 1972, tem-se a figura do censor presente na redação. Outra prova seria que o jornal O São Paulo, juntamente com outros dois periódicos - Tribuna da Imprensa, do Rio de Janeiro, e o alternativo, Movimento, também de São Paulo seriam os últimos periódicos a serem libertados pela censura, em junho de 1978.

\section{ESTUDO DAS MATÉRIAS DO JORNAL O SÃO PAULO}

O período escolhido para estudo permitiu a análise de 763 textos - que englobam matérias, notas, artigos assinados por colaboradores, editoriais (alguns subdivididos em temas diferentes) e, em alguns poucos casos, legendas de fotos.

A escolha pela análise total (e não por amostragem) das matérias se deu por entendermos ser este o método que minimiza ao extremo a chance de se perder algum texto ou posicionamento importante da Igreja no período, ainda mais quando nos lembramos que a censura se fez presente tanto fora como dentro da redação do periódico, ditando o que poderia ou não ser publicado. Foi na esperança de identificar potencial falha, brecha ou descuido da censura e a publicação de um texto sem cortes ou abrandamentos que foi feita a leitura total das edições.

Do montante de matérias, 168 textos não foram aproveitados na dissertação que originou este artigo, pois revelaram-se não condizentes com o objetivo do estudo. Deste modo, 595 textos foram considerados. Para análise de todo esse material foi escolhido a metodologia de enquadramento da mídia, assim definida:

\footnotetext{
Os enquadramentos da mídia [...] organizam o mundo tanto para os jornalistas que escrevem relatos sobre ele, como também, em um grau importante, para nós que recorremos às suas notícias. Enquadramentos da mídia são padrões persistentes de cognição, interpretação e apresentação, de seleção, ênfase e exclusão, através dos quais os manipuladores de símbolos organizam o discurso, seja verbal ou visual, de forma rotineira (GITLIN apud PORTO, 2004, p. 80).
}

Para este artigo, dividiu-se os textos do jornal O São Paulo em cinco enquadramentos distintos. São Eles: Restrito; Plural Fechado, Plural Aberto, Episódico e Avaliativo.

O enquadramento Restrito acontece quando há apenas uma interpretação do fato/evento/ação ou tema; o Plural Fechado quando mais de uma interpretação é apresentada, porém, de maneira hierarquizada, sendo uma interpretação preferida ou destacada sobre as demais; já o Plural Aberto é 
quando mais de uma interpretação é apresentada, e todas estão equânimes; o enquadramento episódico pode ser interpretado como um relato neutro do fato/evento/ação sem apresentar nenhuma interpretação sobre o ocorrido; por fim, o enquadramento avaliativo é aquele que apresenta um juízo de valor explícito no texto.

Após analisados os 595 textos, ficou-se estabelecida a divisão entre os enquadramentos conforme o gráfico 1 :

Gráfico 1: Enquadramentos da mídia aplicados a matérias selecionadas do jornal O São Paulo

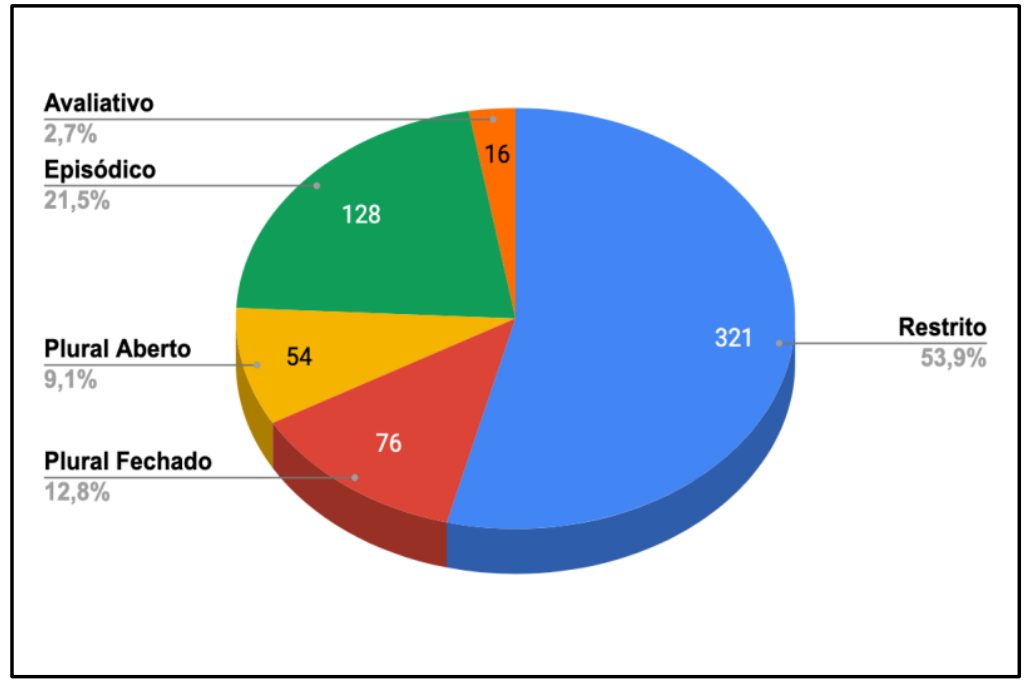

Fonte: Elaborado por Newton Leonardo Silva

\section{Enquadramento Restrito}

Entre as mais de três centenas de textos, alguns chamam a atenção. Por exemplo, a edição de 13 de fevereiro de 1971, na qual há cinco textos onde se encontram apenas uma opinião sobre a prisão do pároco da Igreja São José, no Jardim das Oliveiras, Pe. Giulio Vicini, e da assistente social e secretária da Região Episcopal Sul, Yara Spadini. A razão para tamanha repercussão está no fato de que ambos foram presos no dia 30 de janeiro de 1971. Em resposta, no dia 6 de fevereiro, O São Paulo publicou uma nota de D. Paulo, intitulada "Nota do Arcebispado", na qual este esclarece dez pontos sobre a prisão dos dois membros da Igreja. Entre os pontos estão: "Não podem ser taxados de subversivos sem julgamento em tribunal competente e com direito a ampla defesa" e "Infelizmente, o revdo. Pe. Giulio e D. Yara foram torturados de maneira ignominiosa, no DEOPS de nossa capital, como o Vigário Episcopal da Região Sul e nós pudemos verificar pessoalmente". Além disso, D. Paulo havia solicitado que todas as igrejas fixassem a nota em suas portas no domingo seguinte, porém, sem leitura ou comentários.

Em 13 de maio de 1972 tem-se outro exemplo de texto com apenas uma interpretação. O editorial "A serviço da Verdade" fala a respeito do VI Dia Mundial das Comunicações Sociais (instituído pela Igreja), cujo tema, escolhido pelo Papa, era "Os meios de comunicação social a serviço da verdade". 
O editorial começa relembrando os temas das cinco edições anteriores, fala sobre as obrigações dos meios de comunicação (entre eles, informar lealmente) e termina falando escancaradamente da censura:

Lamentavelmente, como se poderá deduzir até pela situação vivida pelo nosso semanário, nem mesmo a imprensa católica, pela primeira vez em sua história, está encontrando a liberdade para um leal serviço da verdade. Os seus modestos recursos de comunicação encontram-se sob censura e pressões de toda a ordem, sem poder informar e, menos ainda, apreciar, criticamente, os acontecimentos do País. (O São Paulo, 13 de maio de 1972, p. 3)

Outro texto fortemente opinativo e que fala, explicitamente, sobre a tortura (outro assunto impensável de ser mencionado nos demais veículos de comunicação) está na página 10 da edição 854, de 17 de junho de 1972, intitulada: "Mensagem do Episcopado Paulista - Testemunho de Paz". Trata-se da mensagem dos bispos e arcebispos da Regional Sul 1, da CNBB, reunidos entre 6 e 8 de junho em reunião ordinária em Brodósqui. O documento faz acusações e cobra providências de:

[...] fatos já conhecidos tanto dentro de nossas fronteiras, como no estrangeiro, que atentam violentamente contra a incolumidade física, à integridade psíquica, à dignidade da pessoa humana no seu valor moral e religioso [...] [E notório que, apesar dos desmentidos, há bem viva na consciência de nossa população e muito difundida na opinião pública internacional a convicção de que é relevante a incidência dos casos de tortura no Brasil [...] Não é lícito utilizar no interrogatório de pessoas suspeitas, com o fim de obter confissões ou delação de outros, métodos de tortura física, psíquica ou moral, sobretudo quando levados até à mutilação, à quebra da saúde e até à morte, como tem acontecido. (O São Paulo, 17 de junho de 1972, p. 10)

\section{Plural Fechado}

Ao todo, foram 76 textos selecionados no enquadramento Plural Fechado. O primeiro texto a ser ressaltado é o de 13 de maio de 1972, quando o jornal O São Paulo publica uma nota assinada por D. Paulo Evaristo Arns (datada de 11 de maio), na qual este agradece os esclarecimentos "desnecessários" do Pe. Giulio Vicini e de Yara Spadini sobre "informação leviana difundida pelos jornais de 5 e 6 deste mês". A informação referida (só revelada no esclarecimento dos dois, publicado na íntegra abaixo da nota de D. Paulo) é a de que Vicini e Spadini teriam procurado a Ação Popular para ingressarem na organização no Estado Paranaense. "Como se não bastassem os sofrimentos que lhes foram infligidos e as torturas a que foram sujeitos por ocasião de sua detenção no ano passado, vem agora cair sobre suas pessoas [...] novas insinuações que tentam comprometê-los" (O São Paulo, 13 de maio de 1972, p. 7).

Em 31 de março de 1973 é publicada na décima página do semanário a nota do bispo de Sorocaba, D. José Melhado Campos, denunciando violação dos direitos humanos (entendido aqui como tortura e morte no cárcere) de Alexandre Vannucchi Leme. A nota apresenta e questiona veementemente a versão apresentada pela polícia:

Não me compete desmentir as acusações de terrorista e assaltante que a polícia atribuiu ao jovem [...] mas é líquido que, torturando e matando a vítima, essas autoridades policiais, eliminaram barbaramente quem poderia num processo legal, 
defender-se e, se fosse o caso, reconhecer seus atos e responder por eles (O São Paulo, 31 de março de 1973, p. 10)

O último texto a ser ressaltado dentro deste enquadramento é a nota da edição de 2 de março de 1974, intitulada "Lamentável e injuriosa referência a pessoa do cardeal", na qual se repercute o editorial escrito por Carlos Castello Branco na edição de 24 de fevereiro de 1974 do Jornal do Brasil. Comentando sobre a escolha do Dep. Armando Falcão para Ministro da Justiça, Castello Branco critica o líder da equipe governamental, Golbery do Couto e Silva, e, indiretamente, deixa transparecer seu julgamento sobre D. Paulo, o que, no entendimento do jornal, seria a "lamentável, injusta e injuriosa referência": "O próprio general Golbery, a quem se atribui a liderança da equipe governamental, já apareceu de público com D. Paulo Evaristo Arns, o número dois na seleção dos bispos subversivos" (O São Paulo, 2 de março de 1974 , p. 12)

\section{Plural Aberto}

Entre novembro de 1970 e março de 1974, 54 textos apresentaram mais de uma interpretação, sendo que nenhuma delas foi tratada de forma superior ou como a versão correta.

Em 1974, temos a repercussão do fechamento da rádio Nove de Julho, um dos principais veículos de comunicação e, talvez, o com maior alcance, da Cúria de São Paulo. São três as edições que mais chamam a atenção sobre o assunto, dentro deste enquadramento. A edição de 26 de janeiro, em sua página cinco, mostra o depoimento, para um diário católico, do Cardeal François Marty, Primaz da França e Presidente da Conferência Episcopal Francesa; além de um protesto do episcopado belga, publicado pela agência belga de informações C.I.P. Já a edição de 16 de fevereiro, em sua oitava página, traz uma nota afirmando que o Boletim Informativo do Centro de Informações Ecclesia divulgou a íntegra de um artigo da revista Italiana IL Regno-Attualita 74, dedicado ao caso da rádio Nove de Julho, e que o referido artigo deveria ter sido publicado pelo O São Paulo na edição passada. Porém, a nota não deixa claro o motivo da não publicação. Em seguida, tem-se duas mensagens de padres, um de Santa Catarina, outro da cidade de Ponta Grossa. Por fim, a edição de 9 de março de 1974 traz, em sua página 12, texto difundido pela BBC de Londres, em dezembro do ano anterior, sobre o fechamento da rádio. No fim do texto, intitulado "BBC de Londres também noticiou silêncio da Rádio Nove de julho", tem-se a seguinte consideração d'O São Paulo:

Com o fim do governo que decretou o fechamento da Rádio Nove de Julho e como prova de boa vontade para com o próximo Governo Geisel, colocamos aqui um ponto final ao constrangedor problema. Somente fatos novos nos farão retomar outra vez a pena, para falar na Rádio cujo silêncio continua sentido e lamentado por milhares de famílias, de jovens e pessoas de todas as categorias. (O São Paulo, 9 de março de 1974, p. 12)

\section{Episódico}


Ao todo, foram 128 textos nos quais nenhuma interpretação foi apresentada sobre o tema/assunto/fato/evento. Os textos aqui, mais do que em outros enquadramentos, servem como marcos históricos, sem viés ou interpretação, apenas o relato simples e frio sobre determinado assunto.

Dois textos retratam importantes situações vivenciadas por membros da Igreja no período. No dia 15 de julho de 1972 há uma nota, na página 12, sobre o regresso de D. Helder de mais uma viagem à Europa. $\mathrm{O}$ texto reforça que há o acordo para que o arcebispo não se ausente por mais de um mês e viaje, no máximo, quatro vezes ao ano. E acrescenta: "Ele falou de problemas de justiça e política internacional". Mais de um ano depois, em 6 de outubro de 1973, o semanário trazia no canto superior esquerdo da primeira página uma nota com o título "Libertados os dominicanos", na qual informar-se que os frades foram libertados pouco menos de um mês antes de cumprir a pena de quatro anos à qual haviam sido sentenciados anteriormente.

Já no dia 12 de janeiro de 1974, também na primeira página, uma matéria, sem assinatura, denuncia os gastos abusivos para as eleições indiretas para o próximo Presidente da República:

As próximas eleições indiretas do futuro Presidente da República, custarão aos cofres públicos 6 milhões e 200 mil cruzeiros, isto é, cerca de 1 milhão de dólares. [...] Os grandes eleitores receberão $\mathrm{Cr} \$ 10$ mil cada, num total de 5 milhões e 30 mil cruzeiros. [...] O parlamentar que vier de mais distante não dispenderá mais de $\mathrm{Cr} \$ 3$ mil de viagem por avião e em sua permanência em Brasília, por melhor hospedagem que tenha, não gastará mais de Cr\$1.000 (O São Paulo, 12 de janeiro de 1974, p. 1)

\section{Avaliativo}

O último dos enquadramentos realizados se refere aos textos nos quais se emite um juízo de valor. No período pesquisado nesta dissertação, 16 textos foram assim entendidos. O primeiro texto ressaltado, a título de exemplo, é uma nota que data de 19 de dezembro de 1970, que fala, em terceira pessoa, sobre um telegrama que D. Paulo enviou à família do agente federal Hélio Carvalho de Araújo, "traiçoeiramente baleado pelos terroristas que sequestraram o Embaixador da Suíça no Brasil". Como se vê, nesta simples frase é possível identificar o juízo de valor.

Em 25 de setembro de 1971, a coluna "Síntese de 7 dias" (uma espécie de resumo dos acontecimentos da semana, dividida nas subseções "Cidades" e "Brasil") trazia mais uma nota importante historicamente. Sob o título "Carlos Lamarca tomba na Bahia", a nota expõe juízo de valor sobre o assunto em pauta: "Mais uma vez, a violência não compensou e, bem cedo, Lamarca, teve um triste e rápido fim depois de trair sua família, sua Religião e sua Pátria, dando um péssimo exemplo à juventude brasileira" (O São Paulo, 25 de setembro de 1971, p. 2).

Além dos assuntos mencionados acima (como a prisão do Pe. Vicini e de Yara Spadini, o fim da concessão da Rádio Nove de Julho etc), outros temas de interesse social e religioso foram destaques nas páginas do jornal O São Paulo. Por exemplo, os 25 anos da Declaração Universal dos Direitos Humanos, ganhou espaço em várias edições do jornal, em 1973; ou os quatro editoriais "A Igreja e a Revolução", publicados 
entre 20 de fevereiro e 13 de março de 1971, que visavam fazer uma contextualização histórica da relação da Igreja com o chamada "Movimento de março de 1964".

Igrejas Católicas Brasileiras, Meios de Comunicação Social, Pena de morte, Igreja e Capitalismo ou Igreja e Comunismo e esquadrão da morte são outros exemplos de assuntos encontrados em O São Paulo. Até mesmo temas proibidos pelo Estado - como a tortura, notícias sobre D. Helder e eleições foram noticiadas nas páginas do semanário. Decorre daí a importância e singularidade do jornal paulistano.

\section{CONCLUSÃO}

No período analisado por este artigo, o jornal O São Paulo fez uma cobertura extremamente opinativa, como fica evidente ao detectarmos que mais da metade (321 ou 53,9\%) das 595 matérias foram enquadradas no perfil restritivo, ou seja, quando há apenas uma interpretação do fato/evento/ação. Esses dados revelam o espírito do arcebispo que estava à frente do Arcebispado da cidade de São Paulo, D. Paulo Evaristo Arns, que optou pelo enfrentamento aos militares de forma enfática, porém respeitosa e diplomática, e em território nacional.

Esse enfrentamento pode ser demonstrado pela forma como temas sensíveis ao governo ou até mesmo censurados eram abordados pelo semanário. A própria censura aos meios de comunicação social foi retratada em diversos textos do jornal O São Paulo, assim como o esquadrão da morte, as prisões arbitrárias, as torturas, os cerceamentos dos direitos civis, notícias sobre D. Helder Câmara, entre outros diversos assuntos inimagináveis de serem vistos nas páginas de outro veículo de comunicação que não o pertencente à Igreja.

Sobre a censura sofrida pelo próprio O São Paulo, apesar de estar presente no dia a dia da redação, ela é muito pouco perceptível nas páginas do jornal, pelo menos a um primeiro olhar. Poucas matérias dão indícios de que isso estava acontecendo, como é o caso da coluna "Espaço Jovem", de 4 de dezembro de 1971. O texto é um tanto desconexo, contém espaçamentos muito grandes e, ao final da coluna, é transmitida uma receita de presépio. Outro exemplo pode ser encontrado na página 9 da edição de 2 de junho de 1973, na qual se encontra um anúncio de página inteira da Telesp. Anúncios eram comuns no semanário, porém ocupavam espaços bem menores. Os editoriais "Uma mensagem universal", de 20 de outubro de 1973, e "10 anos depois do Movimento de Março de 1964", de 29 de março de 1974, também fornecem indícios de que foram censurados, uma vez que a formatação dos textos está feita de tal modo que contemplam espaços em branco.

Porém, a mais clara demonstração, indireta, de censura é a nota contida na coluna "Espaço Jovem". de 8 de janeiro de 1972. Nela se pode ler que "Esta página estava reservada ao Espaço Jovem. Lamentavelmente, não recebemos, até o momento de ir para as máquinas, o material enviado pelos seus 
responsáveis [...] vamos continuar aguardando que o nosso correio cumpra o seu dever" (O São Paulo, 8 de janeiro de 1972, p. 7).

O semanário da Cúria metropolitana de São Paulo também se propôs a analisar, em diversas ocasiões, a relação entre Igreja e Estado. O destaque fica por conta da série de quatro editoriais "A Igreja e a Revolução" (de 20 de fevereiro a 13 de março de 1971). A visão da hierarquia da Igreja, naquele momento, pode ser sintetizada na seguinte passagem do quarto artigo da série, intitulado "A Igreja e a Revolução - o pensamento da CNBB - IV", datado de 13 de março de 1971:

A Igreja-Hierarquia [...] recebeu a vitória do Movimento de Março de 64 com muita
esperança e, até, como um acontecimento providencial. Reconhece, diante da
evidência dos fatos, tudo que a Revolução conseguiu de bom para o país e que se
resume em duas palavras: paz relativa e desenvolvimento. Mas, manifesta, também,
suas preocupações em alguns pontos como os excessos na repressão, a lentidão da
retomada da plenitude democrática, a violação de alguns direitos fundamentais da
pessoa, atritos provocados por certas áreas revolucionárias, podem e devem ser
superadas, porque assim o exigem a consciência nacional e o maior bem da Pátria. $(O$
São Paulo, 13 de março de 1971, p. 3)

Dando um salto temporal, o último mês analisado coincide com os 10 anos do "Movimento de Março de 1964". Apesar da aparente censura (uma vez que há espaços em branco na formatação do texto), a abordagem da relação entre Igreja e Estado feita pelo periódico no editorial "10 anos depois do Movimento de Março de 1964" mostra uma certa benevolência e esperança da Igreja em relação ao governo. Começa defendendo a necessidade do movimento e expõe a simpatia da Igreja para com ele:

\begin{abstract}
Uma só palavra exprimia a situação daquele período: caos. Caos político, caos econômico, caos social. [...] Todo o sistema social, político e econômico brasileiro encontrava-se em vésperas de um colapso que nos colocava à mercê de aventureiros, alguns sabendo, exatamente, o que desejavam: transformar o Brasil em mais um país comunista. [...] Assim, o movimento popular da "Marcha da Família com Deus pela Liberdade" que propiciou o Movimento Militar de Março de 1964, foi recebido com geral simpatia, inclusive por parte da própria Igreja. Naqueles dias, era indiscutível que os dois Movimentos foram deflagrados para que se restaurassem no Brasil três grandes valores: a democracia, a segurança social e o desenvolvimento. (O São Paulo, 29 de março de 1974, p. 3)
\end{abstract}

No texto ainda há a interpretação do famoso documento de 2 de junho de 1964, por meio do qual a CNBB opina sobre o recém-instaurado governo, "reconhecendo-lhe os inegáveis méritos, recordando os perigos afastados e já, então, apontando com franqueza alguns injustificáveis excessos", e termina fazendo um balanço do três governos anteriores e do novo governo, que se iniciaria em 1974: "os três governos revolucionários conseguiram tornar realidade duas das aspirações iniciais: segurança social e desenvolvimento econômico. O novo Governo Geisel parece excepcionalmente dotado, para promover a realização da outra profunda aspiração: democracia" (O São Paulo, 29 de março de 1974, p. $3)$. 
Além de se propor a analisar a relação entre Igreja e Estado, O São Paulo também fez, ao final do período estudado, uma autoanálise acurada sobre a cobertura realizada pelo periódico no período em que esteve sob o comando de D. Paulo:

O São Paulo, nestes cinco últimos anos, tem procurado seguir esses rumos. Se se desejar, tem feito política no mais alto sentido da palavra, a saber, tem procurado promover o verdadeiro bem da "polis", que somente pode ser o bem comum, o bem de todos e de cada um, integral, sem distorções (O São Paulo, 9 de março de 1974, p. 3)

Por fim, a conclusão a que se chega sobre o papel da Igreja no período estudado, em especial sobre D. Paulo Evaristo Arns, pode ser traduzido por um trecho do editorial "Igreja e Direitos Humanos no Brasil", de 8 de dezembro de 1973:

É certo que sempre se poderá dizer que a Igreja deveria ter feito mais no passado e no presente [...] Mas todos haverão de convir que amanhã, não se poderá dizer que a Igreja foi omissa. Ao contrário, escrever-se-á que a Igreja, deliberada e conscientemente, renunciou a antigos privilégios, alinhou-se ao lado do povo e propugnou pelos Direitos Humanos, sem temer riscos e incompreensõe. (O São Paulo, 8 de dezembro de 1973, p.3)

\section{FONTES}

10 anos depois do Movimento de Março de 1964. O São Paulo, São Paulo, 29/03/1974, p. 3.

A Igreja e a Revolução - o pensamento da CNBB IV. O São Paulo, São Paulo, 13/03/1971, p. 3.

ARNS, P. E. Esclarecimento necessário. O São Paulo, São Paulo, 13/05/1972, p. 7.

A serviço da Verdade. O São Paulo, São Paulo, 13/05/1972, p. 3.

BBC de Londres também noticiou silêncio da Rádio Nove de Julho. O São Paulo, São Paulo, 09/03/1974, p. 12.

Bispo de Sorocaba denuncia violação dos direitos humanos. O São Paulo, São Paulo, 31/03/1973, p. 10.

Cardeal Rossi define posição da Igreja sobre subversão. O São Paulo, São Paulo, 15/11/1969, p. 1.

Carlos Lamarca tomba na Bahia. O São Paulo, São Paulo, 25/09/1971, p. 2.

Eleições indiretas do Presidente: 6 milhões. O São Paulo, São Paulo, 12/01/1974, p. 1.

Espaço Jovem. O São Paulo, São Paulo, 08/01/1972, p. 7.

Igreja e Direitos Humanos no Brasil. O São Paulo, São Paulo, 08/12/1973, p. 3.

Jornal Político ou religioso? O São Paulo, São Paulo, 09/03/1974, p. 3.

No DOPS em visita aos Dominicanos presos. O São Paulo, São Paulo, 29/11/1969, p. 1. 
Lamentável e injuriosa referência a pessoa do cardeal. O São Paulo, São Paulo, 02/03/1974, p. 12.

Mensagem do Episcopado Paulista - Testemunho de Paz. O São Paulo, São Paulo, 17/06/1972, p. 10

\section{REFERÊNCIAS}

BOFF, L; BOFF, C. Como fažer teologia da libertação. Rio de Janeiro: Vozes, 2007.

GOMES, P. C. Os bispos católicos e a ditadura militar brasileira: a visão da espionagem. Rio de Janeiro: Record, 2014.

MAINWARING, S. Igreja Católica e política no Brasil. São Paulo: Brasiliense, 2004.

PORTO, M. Enquadramentos da mídia e política. In: RUBIM, A. A. C. (org.). Comunicaşão e política: conceitos e abordagens. Salvador: UFBA, 2004, p. 73-104.

SERBIN, K. P. Diálogos na sombra bispos e militares, tortura e justica social na ditadura. São Paulo: Companhia das Letras, 2001. 
Data de submissão: 14/04/2021

Data de aprovação: 05/05/2021 